\title{
Cluster Theory and Competitive Advantage: The Torquay Surfing Experience
}

\author{
Bob Stewart \\ Victoria University \\ Melbourne \\ Australia \\ James Skinner, \\ Griffith University \\ Gold Coast \\ Queensland \\ Australia \\ Allan Edwards \\ Griffith University \\ Gold Coast \\ Queensland \\ Australia
}




\title{
Cluster Theory and Competitive Advantage: The Torquay Surfing Experience
}

\begin{abstract}
This paper aims to explain the global expansion of the Rip Curl and Quiksilver surfing brands through the lens of Michael Porter's cluster theory of comparative advantage (Porter, 1998). According to Porter, a cluster of linked businesses can generate commercial synergies and strengths that enable it to achieve a global presence even when it is geographically distant from the major world markets.
\end{abstract}

Porter's cluster theory was used to identify the special features of the Torquay region in Australia, and explain how these features provided the conditions for the explosive international growth of these businesses. Particular attention was given to the region's surrounding geography, its imbedded surfing culture, its industry context, the global vision of the founding owners, the organisational processes of Rip Curl and Quiksilver, the competitive climate, and finally, their capacity to secure marketing opportunities. Data was collected though interviews, document analysis, and field trips to the Torquay region.

The data was interpreted through the prism of Porter's cluster theory of competitive advantage (Porter, 1998). It was found that the historical origins of the Rip Curl and Quiksilver centred on the unique surf culture of the surrounding region. The Torquay district not only had some of Australian best surf beaches, but had also attracted a passionate surfing community that constituted the foundation market for Rip Curl and Quiksilver products. The early successes of Rip Curl and Quiksilver were not only the result of this strong surf culture but also the result of their ability to innovate and design superior products, strong inter-organisational 
synergies, and the international exposure from their association with the annual Bells Beach surfing contest. The subsequent global success came from product diversification, and the development of strong brand images through the endorsements of the world's top surfers.

The specific factors behind their global dominance included first, the role that elite-surfer product endorsement and major surf-event sponsorship played in building the brand image of Rip Curl and Quiksilver, and second, the use of their brand images to construct a high degree of credibility within both the serious surfer and young fashion consumer markets. 


\section{Australian Beach Culture}

Australia is the world's only island continent with more kilometres of surfable coastline than any other country in the world (Gliddon, 2002). All of the major capital cities except Canberra are coastline cities and contain many of the world's best surf beaches. They range from Bell`s Beach in Victoria, Margaret River in Western Australia, to Burleigh Heads in Queensland. In the light of Australia's natural advantages in beach and sea it comes as no surprise that surfing has become very popular.

Australia has been in the forefront of surf-board riding, or surfing is it is more colloquially called, since its emergence as an international sport in the 1960s. Surfing's first professional contest, the inaugural world championship, was held at Sydney's Manly beach in 1964. The Ampol Petroleum company sponsored the event, and it attracted the world's best surfers and 40,000 spectators (Booth,1994). Surfing grew rapidly during the 1970s and by the1980s it had developed a strong commercial foundation (Lanagan, 2003). The Coca-Cola company became a major sponsor, and surf-wear businesses used the successes of surfers and their endorsements to help sell their products (Gliddon, 2002).

\section{Australian surfers Bernard Farrelly, Nat Young, Mark Richards, Tom}

Carroll, and Mark Occiluppo have all won the men's world surf-board riding championships, while Layne Beechley has won six world women's surfing championships. These elite performers are the apex of a surfing pyramid which includes a broad base of recreational surfers throughout Australia. Surfing Australia, the governing body of surfing, reported in 2004 that there are 1.8 million recreation surfers in Australia. This surfing community has brought with it a whole set of values, lifestyles, and patterns of consumption which can be located under the general heading of "surfing capital" (Lanagan, 2003, p. 171). 


\section{The Surfing Industry}

Today surfing images and the associated lifestyle are used in marketing campaigns for a wide range of products which at times are unrelated to surfing. This has been achieved through the marketing of surfing as 'a pleasurable and playful lifestyle' (Lanagan, 2003). This has led to the commodification of the industry, resulting in a profitable market based on the sale of surf clothing and other merchandise sold as 'surfwear' (Lanagan, 2003). This allows the non-surfer to 'share in the surfing lifestyle, but not necessarily be identified as a surfer, by the purchase of a style of clothing and other products' (Lanagan, 2003; pp. 173-174). Lanagan adds that: "the physical act of surfing has been appropriated by business interests and commodified to create a lucrative and popular market based on the sales of lifestyle clothing" (p. 174).

Australia has an international reputation for manufacturing quality surfwear, surf-boards, and surf-gear in general. The principal global producers of surfwear are three Australian companies Billabong, Quicksilver and Rip Curl (known as 'The Big Three'). Billabong is publicly listed on the Australian Stock Exchange, Quicksilver is publicly listed on the New York Stock Exchange and Rip Curl, is an Australian company which is still privately operated. Each of these companies has influenced the surfwear revolution through their identification with a lifestyle and the commodification of the industry. In 2002 the annual estimated global sales for Billabong, Rip Curl, and Quiksilver were \$460 million, \$300 million and $\$ 1.5$ billion respectively. According to the former Chief executive Officer of Billabong, Matthew Perrin, the industry was: "riding a wave of more than $10 \%$ compound annual revenue growth"(Gluyas, 2002). These three companies account for $52 \%$ of the global surf wear market. The 'Big Three' gain their credibility: "from 
the fact that they were all founded by people involved with the sport and with a passion for improving it" (Bergin, Chinniah, Njuguna \& Urn, 2005) p. 6).

All three of these companies commenced their operations in Australian regional districts. Billabong commenced on the Gold Coast and both Rip Curl and Quiksilver commenced their operations in Torquay, a small coastal town in Victoria, which is about an hour's drive from Melbourne, the capital city of Victoria. (The location of Torquay relative to Australia's major cities is indicated in Figure 1). Both these brands have horizontally and vertically integrated their production, as well as establishing sales and distribution centres in Torquay. The combined sales of Rip Curl and Quiksilver currently account for $43 \%$ of the global surf-wear market (Gliddon, 2002).

\section{Insert Figure 1}

This raises the question as to how a small regional district of about 10,000 people came to dominate the national and global surf-gear industry so quickly and so comprehensively. In short, just how did two small surf-gear suppliers in such a relatively remote location, and thousands of kilometres away from the lucrative European and North American markets, become, in the space of 25 years, two of the best know global surf-wear brands?

This paper aims to explain the global dominance of the Rip Curl and Quiksilver brands through the prism of Michael Porter's cluster theory of comparative advantage (Porter, 1998). According to Porter: "enduring competitive advantages in a global economy" paradoxically "lie in local things" (Porter, 1998, p. 78). In other words, a cluster of linked businesses can generate commercial synergies and strengths that enable it to achieve a global presence even when it is geographically distant from major world markets. Porter's cluster theory will be used 
to identify the special features of the Torquay region and how these features provided the conditions for the explosive international growth of these businesses. Particular attention will be given to the region's surrounding geography, its imbedded surfing culture, its industry context and competitive climate, the organisational processes, inter-organisational synergies, and strategic decisions of Rip Curl and Quiksilver, and finally, their capacity to secure global marketing opportunities.

\section{Data Collection Instruments}

Data for this research was collected from a number of sources to ensure a diversity of responses (Ezzy, 2002, Patton, 1990). First, semi-structured interviews were conducted with the sales and marketing staff of Rip Curl and Quiksilver, the Surf Coast Local Government planning officer, and the Editor of the Torquay Times Newspaper. This was essential for providing detailed information about the history of the Torquay region, the growth and evolution of Rip Curl and Quiksilver as large commercial surfing organisations, as well as the development of Torquay as a surfing industry cluster. In total, six interviews were carried out in person with interviewees. All interviewees demonstrated a willingness and openness in their responses to the questions posed. The sequence of the interviews followed a combination of the Stewart and Cash (1994) topical sequence method and the Judd, Smith and Kidder (1991) funnel principle. Stewart and Cash defined a topical sequence as a technique that uses the natural discussion of interviews to develop themes. This sequence gives the interviewer the freedom to probe answers and adapt to any response the participant may give. The funnel principle, according to Judd et al. (1991), advocates that the interview should start with general questions and 
issues. For instance: "How did Rip Curl as an organisation begin?" The initial questions should be easy and unchallenging for the participant. As the interview progresses the questions focus on more specific issues. To assist the interviewer, each question contained a series of probes to aid the researchers in focusing on specific themes within the question; as such the funnel principle was also applied when probing for a deeper understanding of the growth and evolution of Rip Curl and Quiksilver and of Torquay as a surfing cluster.

Second, document analysis was undertaken, since the history and context surrounding specific organisational and industry settings comes in part from reviewing newspaper reports and historical documents (Marshall and Rossman, 1999). In order to ensure a detailed knowledge of more recent operational issues, a number of business -related documents were also analysed. They included annual reports from Rip Curl and Quiksilver, consultancy reports on the growth of surfing industry, media releases, and promotional material on the Rip Curl and Quiksilver web-sites. These documents assisted the researchers in understanding the relative growth and evolution of Rip Curl, Quiksilver and the Torquay region. Finally, three field trips were taken to the Torquay region to map the spatial development of the local surf industry. The data was subsequently analysed in the context of Porter's industry cluster model (Porter, 1998).

To ensure the data collected was valid a number of triangulation techniques were adopted using the principles of Hammersley (1992), who argues for the inclusion of triangulation in all qualitative research. This involves the comparison of data relating to the same phenomenon but deriving from different phases of fieldwork and the accounts of different participants differently located in the setting. In so far as participants' accounts of the growth and evolution Rip Curl and Quiksilver, and the Torquay region as a surfing cluster were concerned, the researchers 
attempted to continuously reformulate and reiterate various questions and comments to consolidate or disconfirm their degree of validity or worth. This strategy was employed across individual accounts and within the same account. Triangulation between researchers was also used to determine if inferences drawn were consistent among individuals involved in the research. Finally, technique triangulation that involved comparing and contrasting data from interviews with data arising out of the analysis of documents was used. These forms of triangulation provided a means of checking consistency and congruence of the research findings.

\section{The Nature of Industry Clusters}

Clusters have long been part of the economic landscape, with geographic concentrations of trades and industries in 'industrial districts' apparent long before the Industrial Revolution. According to Johnston (2003) it was: “... Porter`s (1990) seminal analysis of the competitive advantage of nations, and why some countries produce, relatively, so many more competitive firms, that brought the concept of industrial clusters to the attention of both analysts and policy-makers" (p. 5). In his seminal work Porter indicated

Today's economic map of the world is dominated by what I call clusters critical masses, in one place, of unusual competitive success in particular fields. Clusters are a striking feature of virtually every national, regional, state and even metropolitan economy, especially in more economically advanced nations. Clusters are not unique, they are highly typical, and therein lies a paradox: the enduring competitive advantages in a global economy lie increasingly in local things - knowledge, relationships, motivation (Porter 1998, p. 78). 
Porter's cluster theory arose out two seemingly contradictory tendencies in international business. While on one hand there was a globalisation of economic activity, on the other hand there was a trend to localisation in some industries (Brown, 1996, Enright and Roberts, 2001). Porter observed that notwithstanding the globalisation of trade and commerce over recent years, there were still many clusters, or geographically proximate business with linked activities that dominated not only local markets, but also global markets. He identified the information technology industry in California's Silicon Valley, the leather fashion industry in northern Italy, and the film production industry in Hollywood as prime examples. According to Porter, each of these industry clusters enjoy unusual competitive success by offering advantages in: "efficiency, effectiveness and flexibility" (Porter, 1998, p. 80).

Lowe and Miller (2005) discuss how Porter indicates that clusters are based upon four key determinants of competitiveness, which he calls the 'Diamond of Competitive Advantage'. These determinants are:

1. Factor conditions, such as a specialised labour pool, specialised infrastructure, and sometimes selective disadvantages that drive innovation;

2. Home demand, or demanding local customers who push companies to innovate, especially if their tastes or needs anticipate global or local demand;

3. Related and supporting industries, internationally competitive local supplier industries who create business infrastructure and spur innovation and spin-off industries; and

4. Industry strategy, structure, and rivalry, intense local rivalry among local industries that is more motivating than foreign competition, and a local 
"culture" which influences individual industries" attitudes toward innovation and competition. (Lowe and Miller, p. 2).

In addition to these four areas Lowe and Miller suggest Porter includes the roles of chance and government as playing a major part in the development of a competitive environment. In particular they state: "historical accident and/or government action play significant roles in the early development of site location or local industry clusters" (p. 2). Lowe and Miller (2005) illustrated this process as is seen in Figure 2.

\section{Insert Figure 2}

\section{Definition of Clusters}

Porter (1998) has defined a cluster fairly consistently, as: “a geographically proximate group of interconnected companies and associated institutions in a particular field, linked by commonalities and complementarities"' (p. 78). To this, various descriptive statements are added

The geographic scope of a cluster can range from a single city or state to a country or even a network of neighbouring countries. Clusters take varying forms depending on their depth and sophistication, but most include endproduct or service companies, suppliers of specialised inputs, components, machinery, and services; financial institutions; and firms in related industries. Clusters also often include firms in downstream industries; producers of complementary products; specialised infrastructure providers, government, universities and standard-setting agencies. (Porter, 1998, p.199) 
The lack of operational precision in this definition is reflected in Porter`s comment that:

Drawing cluster boundaries is often a matter of degree, and involves a creative process informed by understanding the most important linkages and complementarities across industries and institutions to competition. The strength of these 'spillovers' and their importance to productivity and innovation determine the ultimate boundaries. (Porter, 1998, p. 202)

Primarily, clusters are a combination of institutions, firms, and business that supply a range of linked or related goods and services. These goods and services can be either service-based inputs like consulting services or employee training, or physical inputs like machine tools or raw materials. These goods and services can also be competing outputs, or final goods that are sold in retail outlets. In short: "clusters comprise a set of value-adding chains involving linkages and interdependencies in design, production, marketing, and delivery" (Enright and Roberts, 2001, p.68).

However, an industry cluster comprises more that a few integrated activities or a competitive market place, and this leads onto the second point Porter makes. According to Porter, these activities take place in a confined and clearly designated geographical space. This clearly defined geographical space is important since it enables day-to-day contact and physical proximity. This contact and proximity will include face-to-face relations and ongoing communication between the various industry participants, which: "fosters better coordination and trust" (Porter, 1998, p.80). 
There have been a number of attempts to develop typologies of clusters. Marceau (1999, cited in Johnston, 2003, p. 9) has identified

- Horizontal clusters' between small and medium-sized firms in an industry sector that both compete and collaborate with each other

- Web clusters' between large firms and their core suppliers

- Virtual clusters', where physical co-location is not important

- Emerging clusters', where firms have a common resource base or resource needs, but have only emerging relationships in production and innovation.

There is also recognition that clusters may raise interest and be considered at different levels - for example at the national level, industry or inter-industry level and firm level, or geographically, at the metropolitan, producer region and rural level. Johnston (2003) suggests:

What emerges clearly is that there is no single, standard, 'one size fits all' model of clusters. Every country and region has a different set of clusters, shaped by historic background, national characteristics, the strength of the knowledge base, size, connectedness, R\&D intensity and share of innovative products. (p. 9)

\section{Competitive Advantages of Clusters}

Porter (1998) asserts that industry clusters involve more than just a convenient way of doing business. The advantage comes from clusters creating a competitive edge. Porter suggests that clusters impact on competition in three main ways. First, they can increase the productivity of businesses based in the cluster location. Being part of a cluster allows companies to operate more productively in sourcing inputs; 
accessing information, technology and needed institutions; coordinating with related companies; and measuring and motivating improvement (Porter 1998, p. 81).

Productivity can therefore increase in a number of ways. Clusters will attract a 'pool of specialised and experienced employees', which means "lower search and transaction costs" (Porter, 1998, p. 81), and a greater supply of talented workers with industry linked skills. Clusters will also ensure a deep and specialised supplier base. The ability to source locally will generate lower transaction costs, reduce the need for large inventories, improve inter-organisation communication, and provide easier access to specialist ancillary services. Clusters assist in the building of specialised information bases. These information bases will house: “extensive market, technical, and competitive information” (Porter, 1998, p. 81) which will in turn be diffused to and among the cluster businesses. Clusters also strengthen the linkages between members. Members consequently become mutually interdependent, and the: "good performance by one can boost the success of the other" (p. 81). Clusters can also attract public institutions and goods. In particular, government investment in training and education can be used to design specialist courses to enhance the skills of employees. Finally, local rivalry can lead to improved overall performance. Peer pressure, pride, and the desire to look good can: "spur executives to outdo one another" (p. 83).

Clusters can also produce conditions that lead to greater product development and innovation: Reinforcing the other advantages for innovation is the sheer pressure - competitive pressure, peer pressure, constant comparison - that occurs in a cluster. Executives vie with one another to set their companies apart (Porter 1998, p. 83.) Johnston (2003) suggests that where clusters are surrounded by buyers it is easier to quickly identify emerging customer needs and trends, and adjust production accordingly. That is, they will have a: "better window on the 
market" (Porter, 1998, p. 83). Clusters also enable businesses to learn about evolving technology and services and marketing concepts. The learning can be enhanced by the ease of making site visits, and the ability to quickly arrange face-to-face discussions with supplier and buyers. Clusters also allow greater flexibility and experimentation. Local suppliers and partners can contribute to the innovation process, and more easily accommodate the development of low cost pilot programs and test runs. And, as with productivity, the "sheer pressure" of local competition will stimulate change and lead to better ways of doing things ( p. 83).

Clusters can also lead to the formation of new business that further extends the cycle of productivity and innovation. For example, it is likely that new suppliers will proliferate, since a concentrated customer base will lower supplier risks and “make it easier for them to spot market opportunities" (Porter, 1998, p. 84).

Moreover: "a cluster allows each member to benefit as if it had a greater scale or as if it had joined with others formally, without requiring it to sacrifice its flexibility " (p. 80).

Related businesses will also be attracted to the cluster since they will have access to relevant assets, skills, inputs and staff. In addition, a cluster will "present a significant local market", and provide an established business and commercial network (Porter 1998, p. 84). These factors will not only reduce the perceived risks of entry, but also enable a less painful exit if the business fails.

In summary, clusters emerge as a result of the synergies that result from the presence of unique natural resources, shared infrastructure, access to a shared pool of labour, shared market intelligence, access to input suppliers, and proximity to markets (Brown, 1996, Enright and Roberts, 2001, Porter, 1998). Porter notes, however, that the above analysis does little to reveal just how a successful cluster emerges, and how it establishes the initial critical mass of competitive advantage. He 
suggests that clusters have a life cycle that features a birth, evolution, and decline. In other words, even though clusters have many self-sustaining qualities, they are not immune to external pressures, environmental jolts, and in particular, "technological discontinuities" (Porter, 1998, p. 85).

\section{Evolution of Clusters}

According to Porter, clusters of internationally competitive businesses arise from a number of distinctive conditions and circumstances. Initially, a cluster's roots can often be traced to "historical circumstances" (Porter 1998, p. 84). He cites some of the scientific instrument clusters in Massachusetts having their origins in the research done at MIT and Harvard University. Clusters can also arise from: “stringent local demand" (Porter 1998, p. 84). For example, Israel’s irrigation equipment clusters can be explained by the regions need for self-sufficiency combined with its water shortages.

Clusters can spring from the: "prior existence of supplying industries", or indeed the proximity of existing clusters (Porter 1998, p. 85). For example, the golf equipment cluster near San Diego has it roots in the nearby aerospace cluster that provided a pool of casting suppliers and engineers. Clusters can also arise from one or two innovative companies that stimulate the growth of each other. Hollywood is good example of this tendency with: "many film makers, production companies, script-writers, technical experts, and actors competing for the hearts and minds of cinema goers" (Porter, 1998, p. 84).

Finally, clusters can sometimes be created from a chance event that gives a locality and its existing businesses a new and expanding business opportunity. Porter uses the example of the Omaha, Nebraska, tele-marketing cluster, and describes how the location of the strategic air command, and its need for: "fibre optic 
telecommunication cables, combined with Ohama's central time zone location and easy to understand local accent, underwrote its tele-marketing development" (Porter, 1998, p. 84). Martin and Sunley (2003) however caution against such universal assumptions and suggest that: " the benefits realised from geographical clustering appear to be specific to certain industries at certain stages of development in certain places and are only realised under particular conditions (Glasmeier, 2000, cited in Martin and Sunley, 2003, p. 22). However, they go on to note that even in the case of an industry 'being in the right place at the right time' it does not mean that the main cause of economic growth or relative success is the result of the geographical concentration of high growth industries (Martin and Sunley, 2003).

Despite these reservations, Porter (1998) suggests that once a cluster is formed, its growth is promoted by self-reinforcing cycle of productivity, success, competition, the supply of more infrastructure and skilled employees, further training and development, innovation, and another round of productivity increase. At this point the cluster comprises an intersection of "insights, skills, and technologies" which underpins the cluster's competitive advantage (p. 85). However, Porter cautiously notes that clusters can lose their competitive edge through internal rigidities, anti-competitive practices, collusion, excessive government regulation, a dramatic shift in buyer needs, and radical technological improvement in another cluster or industry (p.85).

\section{Clusters in Australia}

Brown (1996) has identified more than 100 clusters in Australia, together with a 'Cluster Scorecard' by which clusters can be assessed against ten key attributes. Based upon a review of literature, interviews and the author's judgement the clusters have been rated in four categories. The surfing cluster located at Torquay was given the highest rating of 'strong'. Johnston (2003) indicates: “Typically a strong cluster 
will have strong horizontal and vertical interactions and produce significantly enhanced outputs such as exports" (p. 21).

\section{Cluster Theory and Sport Practice}

While Porter's model has been used to explain a wide variety of industry cluster successes, it has rarely been applied to sport products and practices. At the same time sport is likely to provide some interesting cases. The sporting equipment and sports wear industries have a strong global presence (Klein, 2000), and it may be possible to locate specific geographical clusters that serve the global market. Furthermore it is suggested that horse breeding in Scone, New South Wales is an example of an emerging cluster. The horse racing industry is an extremely lucrative industry with $70 \%$ of Australia's thoroughbred foals born around Scone in the Hunter value. The primary reason for this is the local climate, and world-class infrastructure that accommodates the Australian horse racing industry.

Similarly, it may be possible to identify elite sport practice clusters where sport leagues, governing bodies, athletes, agents and venues congregate, and which in turn create a pool of facilities, skills, talents and specialist knowledge that can be sold around the world (Bloomfield, 2003). Using the elite sport practice perspective, Porter's model has been used to explain the trend toward the clustering of Australian sport. According to Shilbury (2000), Australia is: "witnessing the creation of individual sport industries on a sport-by-sport basis in the form of sport clusters" (p. 209). Shilbury argues that two examples of this trend are the Australian Football League (AFL) and the Victorian Golf network (VGN). The AFL cluster, which is centred in Melbourne, includes the AFL Commission, the sixteen clubs, the print and electronic media that feeds off football success, sport good retailers, licensees of endorsed AFL products, venue managers, and turf maintenance specialists (Shilbury, 
2000, pp. 210-211). The Victorian Golf network cluster includes public golf courses, private golf clubs, golf suppliers, golf club catering services and course maintenance services (pp. 212-213).

Shilbury (2000) concludes that this move to sport clusters has a number of implications and consequences. First, it will mean a changing role for national and state governing bodies of sport as they try to accommodate the growing influence and financial leverage of the corporate sector, government, and private providers. Second, it is likely to provide additional opportunities for growth, particularly with respect to junior sport development and modified games for targeted groups with special needs. Finally, there will be greater pressure to revamp inter-organisational network, and reshape value chains around the design, production, marketing, support and delivery processes (p. 217).

\section{Cluster Theory and Surfing Capital}

At first glance the Australian surf-gear industry has also grown and developed within a clustered arrangement, with the regions around Sydney, the Gold Coast and Melbourne accounting for most of the value-chain processes.

Moreover, by any measure the Australian surf-gear industry has not only developed a highly profitable local market, but also created a strong global presence.

It has been estimated that the global surf-gear industry is worth more than \$A40 billion in annual turnover (Gluyas, 2002). Whereas the surf-gear market originally comprised surfboards, board-shorts and wet suits, it now includes a vast array of surf related apparel that range from fashion board shorts to sunglasses, watches, and T-shirts. In other words, it has shifted from a narrowly defined market catering to the serious surfer to a fashion-based, boutique clothing industry in direct competition with mainstream clothing. This broadening of the consumer base for 
surf-gear is encapsulated in the informal industry slogan that: "you do not have to surf to wear the gear" (Gliddon, 2002, p. 24).

At the global level the industry is highly competitive with more than 40 different brands. At the same time, the five largest brands (Quiksilver, O'Neill, Ocean Pacific, Billabong and Rip Curl) account for 75\% of total market supply (Gliddon, 2002,). The major brands and their market shares are listed in Table 1.

\section{Insert Table 1}

Three of these brands (Billabong, Rip Curl and Quiksilver) originated in Australia. Moreover, as indicated in an earlier part of this paper, Rip Curl and Quiksilver, which account for $45 \%$ of total global sales, were both established in Torquay a small coastal town in south-west Victoria, Australia. Rip Curl's head office is still located in Torquay, and while Quiksliver's head office is now in the USA, its Torquay facilities are still a core part of its international operations. All of these developments beg the question of how Torquay became a world centre for the design, distribution, and marketing of surf-gear.

The remainder of this paper will address this issue by using Porters cluster theory to analyse the origins, and evolution, and global expansion of Rip Curl and Quiksilver, and the impact these businesses had on the overall development of the Torquay region. The analysis will include an assessment of just how appropriate it is to talk about a Torquay surf-gear cluster. In doing so, we aim to answer the following questions: First, how did the Torquay Surf Coast region of Victoria became an international centre for the supply of surf-gear'? Second, to what extent can we call it the Torquay 'cluster'? Thirdly, what are its competitive advantages, and how 
were they used to build its international reputation and market leadership? And finally, will the Torquay cluster be able to sustain this advantage into the future?

\section{Torquay's Surfing Culture}

The Torquay district is heavily steeped in beach culture, and is the gateway to some of the best surf beaches in Australia. It has been a popular holiday destination for Melbourne residents, and combines protected family style beaches with more rugged beaches that face the pounding waves of the Southern Ocean. It has been a beacon for Victorian surfers for the last 40 years. As surfboard riding captured the imagination of young Australians during the late 1950s and early 1960s, the demand for surf boards and surf-gear in general expanded rapidly. The Torquay district was well placed to exploit the growing demand for surfing products because of its proximity to many popular beaches.

Torquay is also the home of Bells Beach, one of the best known surfing locations in the world. By the middle of the 1960s Bells Beach had gained an international reputation for its quality surf, and attracted surfers from around the world (Lueras, 1984). Bells Beach also became the location for a fully professional surfing contest in 1973. The event was sponsored by Rip Curl which had been operating for around four years (Young, 1983). The event, which was won by Michael Peterson, a world ranked Australian, was a raging success. It gained extensive media coverage, and quickly gained iconic status as a superior surfing location. The Bells Beach event has now been running for 30 years. It is the longest running and most prestigious event on the world professional surfing circuit. 


\section{Torquay's Surfing Capital}

By the end of 1960s, Torquay had become a popular summer holiday and surf town destination. It was a haven for young families seeking a safe and healthy vacation, and a beacon for surfboard riders who wanted strong and consistent surf. It didn't take long for the concomitant growth of businesses and industries to service the special needs of both serious surfers and the more casual beach goers. Many smallscale, cottage-style surfboard businesses set up operations in the Torquay district during this period in response to the growing demand for lighter, faster, and custommade boards (Young, 1983).

\section{$\underline{\text { Rip Curl }}$}

Rip Curl was founded by Brian Singer and Doug Warwick in 1969 when they began crafting surfboards at Torquay using generic moulds from Sydney. These moulds were subsequently shaped and branded with the Rip Curl logo that comprised a lotus flower with 1960s style flamboyant lettering. Torquay was a strategically placed location to build surfboards, since it was the gateway to the Victoria's best and most popular surf beaches. The south-west coast had beautiful beaches, and great surf breaks, but also had cold surf. Singer and Warwick quickly understood that the key to year round surfing was not primarily a customised surfboard, but rather a wet suit that could insulate surfers from the chilly waters of the Southern Ocean and accompanying icy south-westerly winds.

Singer and Warwick used their strong local knowledge and surfing experience to produce highly effective wet suits for serious surfers. In the space of a few months they had put together a wet suit that outperformed its major rival, the North American made O'Neill product. They immediately used this fundamental credibility to build a marketing slogan that centred on the concept of 'made BY 
surfers FOR surfers'. By the end of 1970 Rip Curl employed ten full time staff and six outsourcers who together produced the final wet suit product (Young 1983).

In 1973 they used the growing success and reputation of the Rip Curl brand to sponsor the inaugural Bells beach surfing contest. As a result of the international recognition of the Bells Beach surf event and the glowing reports of many of the worlds best surfers, sales expanded rapidly at both the local and global level. Wayne Lynch, a local surfer with an international reputation, became Rip Curl's first contracted surfer. Lynch, an eccentric recluse, had a strong underground following, and successfully promoted Rip Curl wet suits and boards on the global surf stage (Young, 1983). Lynch became the model by which surf-gear promoters fused the non-conformist values of surfing with the street fashion demand for cool but novel clothing. In the 1980s Rip Curl wet suits had built up an international reputation for quality and reliability, and the company diversified into a range of surf related clothing and accessories. One of the most popular lines was a surf back-pack. During the 1990s it expanded its range of products, consolidated and vertically integrated its local supplier network, and horizontally integrated into snow boards and ski wear. Through the development of these linkages and networks benefits were produced for all firms involved and by 2002 had Rip Curl had become the fifth largest surf wear supplier in the world with its head office located in Torquay.

\section{Quiksilver}

Quiksilver was founded by Alan Green and John Law in the early 1970s. Green was initially involved in Rip Curl but decided to move into the surf apparel field with Law. The initial focus was board-shorts. This was the result of the many complaints by surfers at this time about the poor design and quality of existing garments. The leaden canvas, lace-up front, stove-pipe legs, and thick seams 
conspired to create chronic discomfort (Quiksilver, 2002, p. 2). Having accumulated a pile of critical feedback from surfers, Green and Law completely redesigned their board shorts, and consequently quickly captured the serious surfer market.

Quiksilver board shorts were durable, light, non-chaffing, and quick-drying; everything traditional board shorts were not.

The key to the global spread of Quiksilver came in 1976 when Jeff Hakman a surfer from Hawaii and the USA, won the Bells Beach classic. Hakman was so impressed with Quiksilver's board shorts that he sought agreement to distribute them in the USA. This was the beginning of the rapid rise of Quiksilver as a global sport brand. Hakman distributed the board shorts throughout the American west coast, most of Australia's top surfers wore them, and by the middle of the 1980s Quiksilver became the 'name and logo on everyone's thighs from Sweden to Tahiti' (Young, 1983:135). In 1986, unlike Rip Curl, the governing Board of Quiksilver listed itself on the North American stock exchange as a public company. This strategy generated a large funding base, but it also lead to a major restructuring in the 1990s. The head office was relocated to Huntington in the USA, a European office was set up in France, and Torquay was re-positioned as the head office for Asia and the Pacific. In the meantime Quiksilver expanded its product range, and through its strong exposure in the USA and Europe, became the dominant global sport wear brand in the late 1990s. It now accounts for 37\% of total global surf wear sales (Gliddon, 2002).

\section{Why Torquay?}

So, why did Torquay become such an important location for the design, production, marketing and distribution of surf wear, and why wasn't it Sydney or the Gold Coast, given their endless supply of summer weather and surf beaches? 
There were a number of factors that stimulated the early development of Torquay as a centre for surf-gear.

First, the Torquay region was already a focal point for surfing and as result a strong surfing culture was established. This provided not only a ready market for both Rip Curl and Quiksilver, but also a well-informed and critical one where the special needs of surfers were clearly identified. In the case of Quiksilver, they listened to the many complaints about the poor quality and uncomfortable feel of existing board shorts, and used these complaints to produce superior products that met surfer's specifications. In the case of Rip Curl, the cold ocean currents created a special need for wet suits. This need not only ensured a sizeable market, but also created a ready-made quality control system. Surfers were quick to point out any weaknesses and soft spots in the Rip Curl product. Rip Curl exploited this special need for highly insulated wet suits by designing products of the highest quality that quickly gained an international reputation.

Second, the close proximity of the two suppliers created a strong competitive climate in which ideas for product improvement were shared on one hand, but where innovation was used to provide a marketing edge over its rival on the other. In other words, they captured the corporate synergies that came from their location in a tightly organised region where their products could be both tested and sold. Specifically, Torquay and its surrounding surf beaches attracted a critical mass of potential users and critical consumers, some of whom were general beach goers, and others who were committed surfers. Moreover, Bells Beach had consolidated its reputation as one of the world's great surfing locations, which in turn attracted more surfers, spectators and sponsors to its Easter surfing competition. Through their sponsorship arrangements, Rip Curl and Quiksilver used the international 
reputation of Bells Beach to both increases their global recognition, and sustain their credibility as integral components of the Australian surfing landscape.

At the same time the growth of the fledgling Torquay cluster attracted an eclectic array of surfing nomads, surf board makers, surf shops, skilled employees, and outsourcers (Young, 1983). This created a number of synergistic interorganisational relationships in which customers, producers and suppliers ensured and ongoing interplay of communication, quality materials, experienced staff, suppliers and outsourcers, and well informed users of the final product (Gluyus, 2002).

It was clear that by the end of the 1980s the Torquay cluster had consolidated its position as a world leader in surf wear design, production, marketing and distribution. Moreover, it exhibited many of the features that Porter's cluster model proposed. First, the Torquay cluster arose out of "historical circumstances" (Porter 1998, p. 84) in that the Torquay region was at the forefront of the surfing movement in the 1960s, and its beaches were recognised locations for quality surf. Second, the Torquay cluster arose out of "stringent local demand" (Porter 1998, p. 85) in that the local surfing community had a very clear idea of what constituted quality surf wear. There is no doubt that the benchmark designs of wet suits and board shorts in the Torquay cluster were the result of the clearly expressed needs of experience surfers, who confirmed the competitive advantage to be gained by working with "sophisticated customers' from the local region (Porter, 1998, p. 90). Finally, the Torquay cluster arose from "one or two innovative companies that stimulate the growth of each other" (Porter 1998, p. 84). While in the early years Rip Curl and Quiksilver specialised in different products, their markets were identical. In addition, they soon began to offer competing products, and the rivalry and 
competitive pressures increased as a result. The factors that created and sustained the Torquay cluster are represented in Table 2.

\section{Insert Table 2}

\section{What Strengthened the Torquay Cluster?}

The key to Torquay cluster's continuing growth in the 1990s and beyond was its early acknowledgment that its local knowledge, inter-organisational relationships, local supply chains, and retail successes could be translated to the world surf-gear market. In the first place, both businesses were quick to create international recognition for their brands. This was done by initially riding the wave of Australia's image as a world centre of surfing. It was quickly followed by a strategy of aligning their products highly successful and marketable surfers. Quiksilver's success in using Jeff Hakman to promote their board shorts in the 1970s was used a template for its 1980s sales and marketing campaign. This time it contracted Tom Carroll, Australia's world champion in 1983 and 1984 to endorse and promote its products. Carroll was an ideal representative for Quiksilver products. He was both the world's premier professional surfer, and also a symbol of daring innovation through his radically different power surfing style. In 1990 it snared Kelly Slater, a talented and popular surfer from the USA to endorse its products. Slater went on to win six world championships. In each case, the testimonials of the world's best surfers were used to confirm the global credibility of the brands.

Throughout the 1990s both Rip Curl and Quiksilver also copied the Nike strategy of contracting out their production (Goldman and Papson, 1998). This was initially done in the Torquay region, but with in a few years it was obvious that large cost savings could be achieved by taking their production offshore. Rip Curl 
developed a supplier network in Thailand, while Quiksilver's major offshore suppliers were located in China.

Again, like Nike, both Rip Curl and Quiksilver differentiated their products on the basis of style and image as well as function. Functionality was initially important because it gave a foundation level of credibility to their products. In the case of Rip Curl, it was important to confirm in the minds of serious surfers that its wet suit out performed its rivals. Quiksilver also used functionality as the basis of its board shorts promotion, and used testimonials from experienced surfers that made it clear that they were the most comfortable and durable. At the same time, they also understood that surfing was alternative rather than mainstream, and rebellious rather than conformist. To this end they promoted their products as not only comfortable and casual, but most importantly, cool. This was an important product feature and brand image for the $12-24$ year old age group, who comprised the single largest market segment for surf wear (Gliddon, 2002). For example, in the early 1980s Quiksilver released the outrageously provocative Echo beach prints that included polka dots, triangles, and checkerboards. This was closely followed by the colourful war paint series of board shorts in the late 1980s.

Rip Curl and Quiksilver were also able to successfully extend their operations into two linked but distinctive areas. The first was the rapidly growing extreme and adventure sport field. Their credibility in surfboard making was translated into the design and distribution of snow-boards and skateboards, which was additionally linked to the supply of branded accessories like sun glasses and wrist watches. By the 1990s Rip Curl had assembled a range of mountain wear that included ski-suits, gloves, and sunglasses. In 1999 Quiksilver bought out the Hawke Clothing Company and its owner Tony Hawke, the world's best know skateboarder. This diversification into ski and skate wear provided both Rip Curl and Quiksilver with all year round 
sales, thus ironing out seasonal fluctuations. The second was the fashion area. This was achieved by using the alternative image of surfing to construct an image of cool rebellion that was described above. This allowed non-surfers to comfortably identify with Rip Curl and Quiksilver. By wearing the gear, they could appropriate the surfer image without having to learn to surf, or indeed ever get wet (Chevalier and Mazzalovo, 2004). In addition, Rip Curl and Quiksilver increasingly targeted females. Quiksilver in particular was highly successful in the 1990s with its Roxy range of surf wear which catered for the growing number of women who either surfed or wanted to look like surfers.

Rip Curl and Quiksilver were also obsessive innovators who understood how technology and good design could produce both superior product performance and fashionable appearance. In the case of Rip Curl, the Elastomax and Slickskin technologies set international standards for wet suit design. In the case of Quiksilver the introduction of concept stores were highly successful in attracting many more street fashion customers, and generally creating a much broader base of brand awareness and recognition (Chevalier and Mazzalovo, 2004).

At the same time, Rip Curl and Quiksilver continued to sponsor surf events around the world. They ranged from the Bell's Beach Easter surf classic, the world amateur surfing championships, and numerous men's and women's events in Europe, to major events in the USA, including the Big Wave international series in Hawaii. Their brand names consequently became synonymous with surfing in general, and when combined with product endorsements from the world top surfers, generated enormous brand recognition, credibility and appeal (Klein, 2000). At the same time they also symbolised the hedonistic, individualistic and alternative values that underpinned the culture of surfing. They had become, in short, the archetypal sport brands (Mark and Pearson, 2001). 
Finally, the Torquay region continued to attract additional materials suppliers, surf-board makers, and distribution outlets. This enabled the cluster to consolidate its value chain and achieve further synergistic benefits its members while at the same time promoting local competitiveness, innovation and growth.

As a result of these initiatives both Rip Curl and Quiksilver were able to develop a strong design and marketing presence in Europe and North America, the two largest markets for surf wear. By 2002, 90\% of total Quiksilver sales came from these markets. The factors that enabled the Torquay cluster to expand it operations on a global scale are illustrated in table 3.

\section{Insert Table 3}

\section{Concluding Comments}

In explaining the origins and evolution of clusters, Porter talks about things like historical circumstances, the impact of stringent local demand, the prior existence of supplying industries, and chance events that create business opportunity. When talking about the development of competitive advantage, Porter highlights the ways in which the availability of specialist staff, specialist information bases, and local rivalry can improve efficiency. Porter also highlights the ways in which easy access to suppliers, buyers, and customers can lead to product development and innovation. Porter also notes the importance of how clusters entice other suppliers into the region. In the case of the Torquay cluster, historical circumstance, stringent local demand, and the innovation that comes from intracluster rivalry were instrumental in its early development. Porter's cluster model therefore provides a useful frame for explaining the early growth of the Torquay 
surfing industry. The interrelationships within the Torquay surfing cluster are highlighted in Figure 3.

\section{Insert Figure 3}

In explaining its subsequent international growth the combination of local rivalry and the obsessive desire to seize market opportunities were two very important factors. This highly competitive local climate in turn created a culture of innovation where products were continually tested on local beaches, and sold in local retail outlets to discerning customers. Porter's argument that clusters create a self reinforcing cycle of productivity, success, further productivity, and more success, through the "sheer pressure of competition" (Porter 1998, p. 83) the presence of a "significant local market" (p. 84) and the ability to "spot market opportunities" (p. 84), perfectly illustrates Torquay's development.

On the other hand, there is one crucial strategy Porter does not highlight, but which was pivotal to the Torquay surf-gear cluster's success. As we indicated in the early part of this paper, surfing culture was for the most part anti-establishment and alternative. This meant that surfers gave credibility to those products that were designed and supplied by fellow surfers. In their formative years Rip Curl and Quiksilver did this better than any other surf-gear supplier, since both companies were owned by experienced surfers. From the 1980s onward Rip Curl and Quicksilver used both major surf events and high profile professional surfers to give legitimacy and credibility to their products. This has become a special feature of sport product marketing, with Nike and their association with Michael Jordon being the international exemplar (McDonald and Andrews, 2001). Rip Curl and Quiksilver have covered similar terrain in the quest for global dominance. 
In summary, Porter's cluster theory provides a highly useful frame for explaining how the Torquay region became such an important supplier of surf-gear for the global market. In turn, the Torquay surf-gear cluster reveals how local strengths and advantages, constant innovation, product improvement, and a strong brand name and image can be used to achieve global dominance. However, the future success of the cluster is unclear as the benefits realised from geographical clustering appear to be specific to certain industries at certain stages of development in certain places and are only realised under particular conditions (Glasmeier, 2000, cited in Martin and Sunley, 2003, p. 22). It could be argued, that the Torquay cluster now operates in a new environmental conditions and circumstances which may threaten its continued viability.

Finally, it is still not clear just how useful the Porter model is when it comes to understanding the clustering of sport practices around sport governing bodies, sport leagues, sport training institutes, and sport venues. Shilbury (2000) has tested the water and provided some useful guides for further research. In addition, an intuitive case can be made for a sport practice clustering at the Bruce sporting complex in Canberra, the Homebush Olympic Centre in Sydney, and the Olympic Park sport precinct in Melbourne. Within this context, Porters' cluster model of competitive advantage is likely to provide an effective conceptual frame for an analysis of how these sports clusters formed, the factors that stimulated their subsequent development, and the extent to which they will be sustainable in the long-term future. 


\section{References}

Bergin, C., Chinniah, I., Njuguna, G. \& Urn, D. (2005) Billabong International - Surf's Up. Internet: www.johnwiley.com.au (accessed January 7, 2005)

Bloomfield, J. (2003) Australia's Sporting Success: The Inside Story, Sydney: University of New South Wales Press.

Booth, D. (1994) Swimming, surfing and lifesaving, in Sport in Australia: A Social History(Eds, Vamplew, W. and Stoddart, B.) Melbourne: Cambridge University Press.

Brown, R. (1996) Industry Clusters in an Australian Context, Canberra: ANZ Regional Science Association.

Chevalier, M. and Mazzalovo, G. (2004) Pro Logo: Brands as a Factor of Progress, Basingstoke: Palgrave Macmillan.

Enright, M. \& Roberts, B. (2001). Regional Clustering in Australia. Australian Journal of Management, 26, pp. 65-86

Ezzy, D. (2002) Qualitative Analysis: Practice and Innovation, Crows Nest: Allen and Unwin.

Gliddon, J. (2002) Mad Wax, The Bulletin, August 13, 20-25.

Gluyas, R. (2002) Wet Suits, The Weekend Australian, February 23, 27-30. 
Goldman, R. and Papson, S. (1998) NIKE Culture: The Sign of the Swoosh, London: Sage Publications.

Hammersley, M. (1992). What's Wrong with Ethnography: Methodological Explorations. London: Routledge.

Johnston, R. (2003, March). Clusters: A Review Prepared for Mapping Australian Science and Innovation, Department of Education, Science and Training.

Judd, C., Smith, E., \& Kidder, L. (1991). Research Methods in Social Relations, Fort Worth: Harcourt Brace Jovanovich

Klein, N. (2000) No Logo: No Space, No Choice, No Jobs, London: Flamingo.

Lanagan, D. (2003) Dropping In: Surfing Identity Community and Culture. In J. Skinner, K. Gilbert, \& A. Edwards, (Eds). Some Like It Hot: The Beach as a Cultural Dimension (pp. 169-184). Oxford: Meyer and Meyer Sport.

Lowe, J., and Miller, P., Business Clustering: Panacea or Placebo for Regional Australia? The Regional Institute Ltd. Internet: http://www:regional.org.au/au/countrytowns/options/miller.htm?print=1 (accessed 07/20/2005).

Lueras, L. (1984) Surfing: The Ultimate Experience, Honolulu: Emphasis International. 
Marceau, J., The Disappearing Trick: Clusters in the Australian Economy, Chapter 6 in OECD, Boosting Innovation : The Cluster Approach, Paris, 1999.

Mark, M. and Pearson, C. (2001) The Hero and the Outlaw: Building Extraordinary Brands Through the Power of Archetypes, New York: McGraw Hill.

Marshall, C. M., \& Rossman, G. B. (1999). Designing Qualitative Research. London: Sage.

Martin, R. \& Sunley, P. (2003). Deconstructing Clusters: Chaotic Concept or Policy Panacea? Journal of Economic Geography, 3, pp. 5-35

McDonald, M. and Andrews, D. (2001) Michael Jordon: Corporate Sport and Postmodern Celebrityhood. In D. Andrews \& S. Jackson (Eds). Sport Stars: The Cultural Politics of the Sporting Celebrity (pp. 20-36) London: Routledge.

Patton, M. (1990) Qualitative Evaluation and Research Methods, Newbury Park: Sage. Porter, M. (1990). The Competitive Advantage of Nations. London: Macmillan

Porter, M. (1998) Clusters and the New Economics of Competition, Harvard Business Review, November, 77-90.

Quiksilver Inc. (2002) Annual Report, Huntington. 
Shilbury, D. (2000) Considering Future Sport Delivery Systems, Sport Management Review, 3 (2), 199-221.

Stewart, C. J., \& Cash, W. B. (1994). Interviewing: Principles and practice, Madison, WI: Brown

Young, N. (1983) The History of Surfing, Palm Beach: Palm Beach Press. 
Figure 1: Australia and the Torquay Surf-gear Cluster

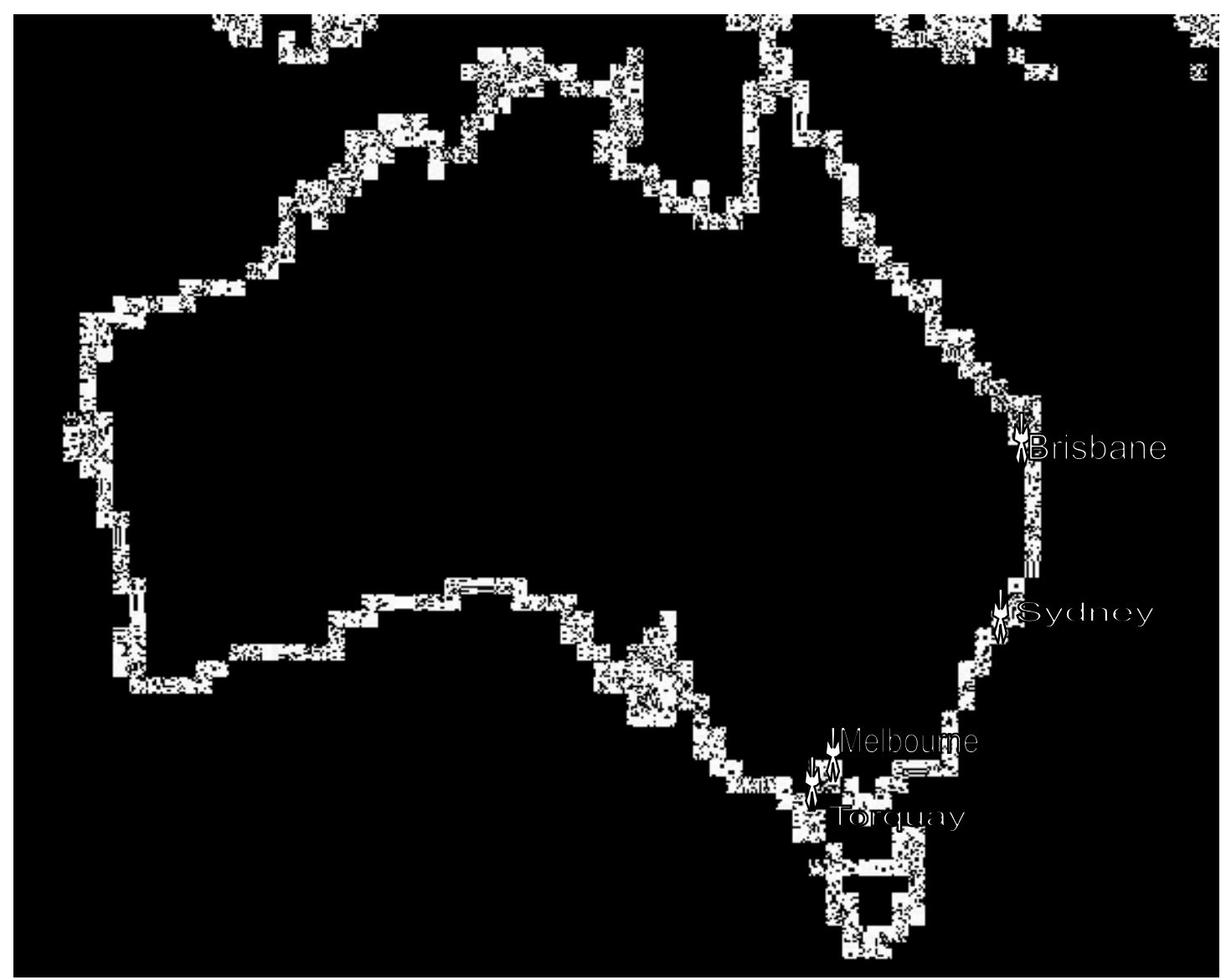


Figure 2: Sources of Locational Competitive Advantage.

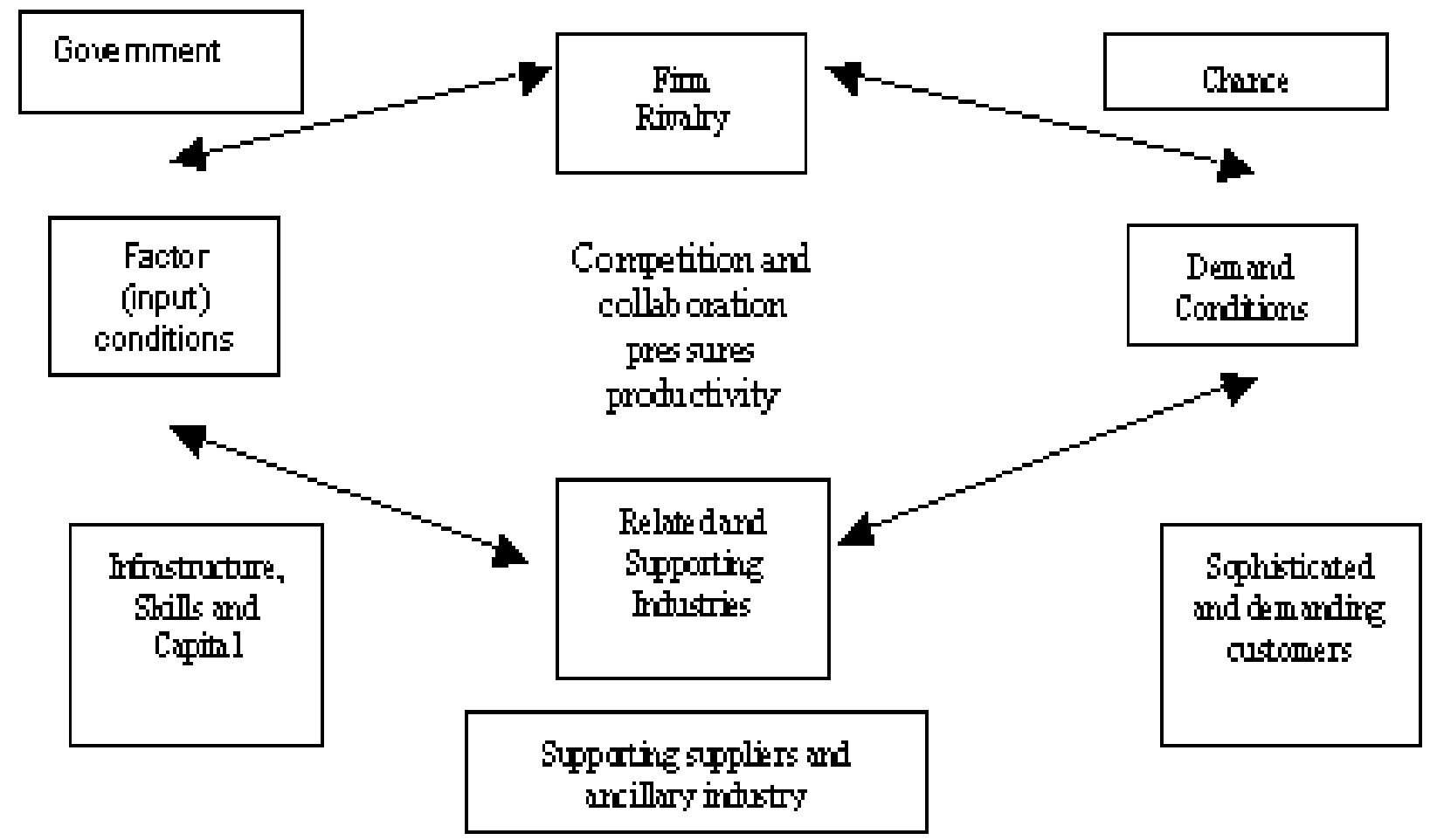

(Cited in Lowe and Miller, 2005, p. 2) 


\section{Figure 3: The Torquay Surfing Cluster}

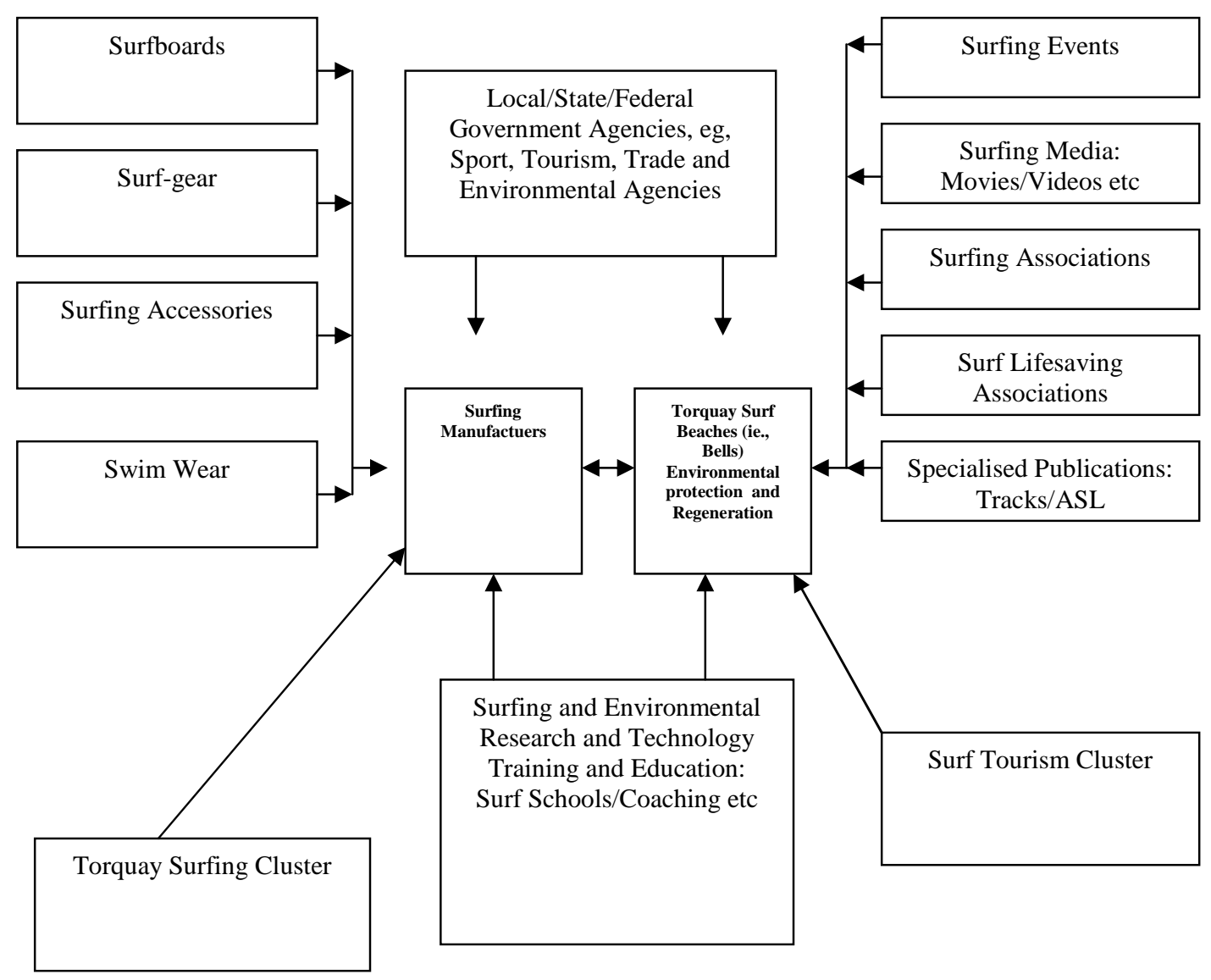

Adapted from Porter, 1998, cited in Lowe and Miller 2003, p. 4) 
Table 1: Global Surf-wear Market: Major Suppliers

\begin{tabular}{|l|l|l|}
\hline Brand name & Market share (\%) & $\begin{array}{l}\text { Estimated sales } \\
\text { (wholesale) }\end{array}$ \\
\hline Quiksilver & 37 & \$A1.5 billion \\
\hline O'Neill & 14 & \$A600 million \\
\hline Ocean Pacific & 9 & \$A400 million \\
\hline Billabong & 9 & \$A380 million \\
\hline Rip Curl & 8 & \$A300 million \\
\hline Oxbow & 3 & \$A120 million \\
\hline Rusty & 3 & \$A100 million \\
\hline Volcom & 3 & \$A100 million \\
\hline Hurley & 2 & \$A80 million \\
\hline Mambo & 2 & \$A70 million \\
\hline
\end{tabular}

Source: R. Guyas (2002) ‘Wet Suits' The Weekend Australian , February 23-24 p.27. 
Table 2: Core factors in the Establishment of the Torquay Surf-gear Cluster

\begin{tabular}{|l|l|l|l|}
\hline Communities & $\begin{array}{l}\text { Facilities, events } \\
\text { And relationships }\end{array}$ & $\begin{array}{l}\text { Suppliers and } \\
\text { inputs }\end{array}$ & Markets \\
\hline Local surfers & Local surf beaches & Rip Curl & Local sales \\
\hline Out of town surfers & Bells Beach contest & Quiksilver & Brand awareness \\
\hline $\begin{array}{l}\text { Our of town } \\
\text { visitors }\end{array}$ & Event sponsorship & $\begin{array}{l}\text { Other suppliers } \\
\text { and competition }\end{array}$ & Brand credibility \\
\hline Local suppliers & $\begin{array}{l}\text { Product } \\
\text { endorsement }\end{array}$ & $\begin{array}{l}\text { Skilled staff and } \\
\text { local outsourcers }\end{array}$ & International sales \\
\hline
\end{tabular}


Table 3: Core Factors in the Global Expansion of the Torquay Surf-gear Cluster Products

\begin{tabular}{|c|c|c|}
\hline Strategic initiative & Cases and examples & Expected benefits \\
\hline Contracting out & $\begin{array}{l}\text { Off shore production in } \\
\text { Thailand and China }\end{array}$ & Lower production costs \\
\hline Market development & $\begin{array}{l}\text { Snow skiing and } \\
\text { skateboarding }\end{array}$ & Increase in global sales \\
\hline Product Diversification & $\begin{array}{l}\text { Product range extension to } \\
\text { include back packs, } \\
\text { footwear, sunglasses and } \\
\text { watches }\end{array}$ & $\begin{array}{l}\text { Expansion into new } \\
\text { markets }\end{array}$ \\
\hline Product innovation & $\begin{array}{l}\text { Redesign of board shorts, } \\
\text { and continual } \\
\text { improvement in wet suit } \\
\text { design }\end{array}$ & Competitive advantage \\
\hline Market segmentation & $\begin{array}{l}\text { Targeting females } \\
\text { including exclusive } \\
\text { women's brands like Roxy }\end{array}$ & $\begin{array}{l}\text { Customised products and } \\
\text { brand loyalty }\end{array}$ \\
\hline Superior design & $\begin{array}{l}\text { Rip Curl wet suits } \\
\text { Quiksilver board shorts }\end{array}$ & Competitive advantage \\
\hline Product endorsement & $\begin{array}{l}\text { Lynch, Hakman, Carroll, } \\
\text { Kelly Slater, and Beachley }\end{array}$ & $\begin{array}{l}\text { Brand awareness and } \\
\text { product loyalty }\end{array}$ \\
\hline Event sponsorship & $\begin{array}{l}\text { Bells Beach contest, major } \\
\text { events in Europe and USA }\end{array}$ & $\begin{array}{l}\text { Brand awareness and } \\
\text { product loyallty }\end{array}$ \\
\hline
\end{tabular}

